\title{
A hangszeres zene tanulásában szerepet játszó motivációs tényezők
}

\author{
Földi Fanni ${ }^{1}$ és Józsa Krisztián ${ }^{2}$ \\ ${ }^{1}$ Szegedi Tudományegyetem Neveléstudományi Doktori Iskola \\ ${ }^{2}$ Szegedi Tudományegyetem Neveléstudományi Intézet, Magyar Agrár-és Élettudományi \\ Egyetem Neveléstudományi Intézet
}

\begin{abstract}
Absztrakt
A tanulmányban a hangszeres zenét tanuló diákok motivációját elemezzük. A hazai motivációkutatások eddig még alig vizsgálták a hangszeres zenetanulás motivációs hátterét, ezért fókuszálunk erre a területre. Kutatásunk a Motivation for Learning Music (MLM, hangszertanulási motiváció) kérdőívet alkalmaztuk, melyet magyar nyelvre adaptáltunk. A vizsgálati eszközt az öndeterminációs elmélet alapján dolgozták ki. Összesen 25 Likert-típusú állítást tartalmaz, melyek a következő faktorokba rendeződnek: motiválatlanság, külső szabályozás, introjekció, azonosulás és intrinzik motiváció. A vizsgálatban 10-18 éves tanulók vettek részt, összesen 151 fö. A mérőeszköz faktoriális validitása és az öt skála reliabilitása megfelelő. Elemzéseink rámutatnak, hogy a középfokon tanuló diákok motiváltsága erősebb, mint az alapfokon tanulóké. Eltérés van a különböző hangszereken tanulók elköteleződésében. Nincs azonban különbség a fiúk és a lányok motiváltságában. A hangszertanulás iránti motiváltságban szerepet játszik a gyermek önállóságának, autonómiájának támogatása. A kutatás eredményei hozzájárulhatnak, hogy mélyebben megismerjük a zenét tanuló diákok motivációját.
\end{abstract}

Kulcsszavak: motiváció, hangszertanulás, öndeterminációs elmélet

\section{Bevezetés}

Az emberek zenéhez, zenetanuláshoz való viszonyulás jelentősen eltérő. A motiváció mértéke, típusa erősen befolyásolja, hogy miként vesznek részt a zenei képzésben. Az intrinzik motiváció mint a tevékenység öröme, az elégedettség érzése, vagy az extrinzik motiváció, mint például a hírnév, a jutalom, a büntetéstől való félelem hatással vannak a zenetanulás melletti elköteleződésre (Appelgren et al., 2019).

Írásunkban a hangszeres zenetanulással foglalkozunk. Tanulmányunk célja, hogy az öndeterminációs elmélet keretén belül értelmezve képet kapjunk a diákok hangszertanulási motivációjáról. Vizsgálatunkban 10-18 éves diákok 
kérdőíves adatgyüjtését végeztük. A hasanló hazai kutatások elsősorban az iskolai ének-zene tantárgyra irányultak, így egyelőre a hangszeres zenetanulás motivációjáról keveset tudunk. Kutatásunk az első ilyen irányú vizsgálat Magyarországon.

\section{Zenetanulás és motiváció}

A zenetanulás és a motiváció kapcsolatára vonatkozó külföldi kutatások már több évtizeddel ezelőtt elindultak. A zenetanulást befolyásoló tényezők vizsgálatát több tanulmány is a középpontba helyezte (például Hargreaves \& Marshall, 2003). A nemzetközi kutatások igazolták például a szülők (McPherson \& Zimmerman, 2002; McPherson, 2009), a pedagógusok (McPherson \& McCormick, 2006), valamint a kortársak fontos szerepét (Längler et al., 2018). Janurik Márta (2007) kutatása a flow szerepét emeli ki. Cantero és JausetBerrocal (2017) szerint a tanulók zene iránti szeretete az egyik legfontosabb a motiváció fenntartásában. Bernabé-Valero és munkatársai (2019) különböző motivációs elméletek alapján keresték a választ arra, hogy mi motiválja a diákok zenei elköteleződését. Ezen elméletek főként arra vonatkoztak, hogy a tanulók hogyan ítélik meg saját képességeiket, mennyire elégedettek elért eredményeikkel, milyen mértékű erőfeszítést tesznek a hangszertanulás során, mennyire tartják fontosnak ezt a tevékenységet.

A motiváció meghatározása nem egyszerü, hiszen a pszichológia minden területén megjelent egy-egy elmélet azzal kapcsolatban, hogy mi ösztönöz minket egy cselekvés elvégzésére. A főbb elméletek Oliveira és munkatársainak (2021) áttekintése szerint: öndeterminációs elmélet (self-determination theory), elvárás-érték elmélet (expectancy-value theory), oktulajdonítás (attribution theory), teljesítmény-cél elmélet (achievement-goal theory), önszabályozás (self-regulation), önhatékonyság és csoporthatékonyság (self-efficacy, group efficacy).

Vizsgálatunkban - a fentebbi elméletek közül - az öndeterminációs elméletet vettük alapul. A Ryan és Deci $(2017,2018)$ nevéhez füződő elmélet három fő szükségletet emel ki: az autonómiát, a kompetenciát és a személyes kapcsolatokat, amelyek együttes átélésével, kielégítésével válik a cselekvésünk önmeghatározottá. Autonómia során cselekvéseinket saját akaratunkból végezzük, ami így az egyéniségünkhöz, az érzéseinkhez illeszkedik. A kompetencia a képességeink gyakorlását, növelését és fejlesztését jelenti, ezáltal saját hatékonyságunkat éljük meg. A harmadik, a kapcsolati szükséglet, amely során egy közösség tagjának érezzük magunkat, annak az érzése, hogy tartozunk valakikhez (Kö et al., 2017).

Az elmélet különbséget tesz a motiváció egyes típusai között, így az autonóm és az ellenőrzött motívumok, illetve a motiválatlanság között. $\mathrm{Az}$ autonóm motiváció forrása az én, személyes célokból, értékekből és érdekből indul ki, az élvezeten, a tevékenységben lelt örömön alapszik. Ezen motivációs típusok pozitívan hatnak a tanulási eredményekre, a jobb telje- 
sítményre, növelik az elkötelezettséget és a kitartást, hozzájárulnak a pozitív önértékeléshez és a jobb közérzethez (Ryan \& Deci, 2009). Az ellenőrzött vagy kontrollált motiváció a külső és belső nyomást jelenti, a motiválatlanság pedig bármilyen cél vagy késztetés hiányát jelöli. Az ellenőrzött motívumok csökkentik az érdeklődést, jóllétet. Az elmélet a szándékos cselekvés és az elvárt eredmény közötti kapcsolatok feltárását és megértését célozza (Ryan \& Deci, 2009; Comeau et al., 2019).

A zene és az önmeghatározási elmélet kapcsolatára vonatkozó kutatások főként Paul Evans (2015) nevéhez köthetőek. Az 1. táblázat a motivációs típusokat szemlélteti, kiegészítve a zene szempontjából fontos viselkedési mintákkal, amely Evans (2015) vizsgálatain alapszik. A táblázatban szereplő motívumok balról jobbra haladva átmenetet képeznek a motiválatlanság és a belső motiváltság között.

\section{1. táblázat}

A motiváció típusai és a zene szempontjából fontos viselkedési megnyilvánulások (Evans, 2015)

\begin{tabular}{|c|c|c|c|c|c|c|}
\hline $\begin{array}{c}\text { Motivációs } \\
\text { típus }\end{array}$ & \multicolumn{4}{|c|}{ Motiválatlanság } & \multicolumn{2}{|c|}{ Belső motiváltság } \\
\hline $\begin{array}{l}\text { Szabályozási } \\
\text { stílus }\end{array}$ & $\begin{array}{l}\text { Nincs sza- } \\
\text { bályozás }\end{array}$ & $\begin{array}{l}\text { Külső sza- } \\
\text { bályozás }\end{array}$ & $\begin{array}{l}\text { Introjek- } \\
\text { tált szabá- } \\
\text { lyozás }\end{array}$ & $\begin{array}{l}\text { Azonosult } \\
\text { szabályo- } \\
\text { zás }\end{array}$ & $\begin{array}{l}\text { Integrált } \\
\text { szabályo- } \\
\text { zás } \\
\end{array}$ & $\begin{array}{l}\text { Belső sza- } \\
\text { bályozás }\end{array}$ \\
\hline $\begin{array}{l}\text { A viselkedés } \\
\text { jellemzője }\end{array}$ & \multicolumn{5}{|c|}{ Kontroll } & $\begin{array}{l}\text { Öndeter- } \\
\text { mináció }\end{array}$ \\
\hline $\begin{array}{c}\text { Észlelt okság } \\
\text { helye }\end{array}$ & $\begin{array}{l}\text { Személy- } \\
\text { telen }\end{array}$ & Külső & $\begin{array}{l}\text { Valame- } \\
\text { lyest külső }\end{array}$ & $\begin{array}{l}\text { Valame- } \\
\text { lyest belső }\end{array}$ & Belső & Belső \\
\hline $\begin{array}{l}\text { Viselkedési } \\
\text { jellemzők }\end{array}$ & $\begin{array}{l}\text { Szándék } \\
\text { hiánya } \\
\text { nem ér- } \\
\text { téknövelő } \\
\text { Kompe- } \\
\text { tencia } \\
\text { hiánya }\end{array}$ & $\begin{array}{l}\text { Külső juta- } \\
\text { lom, vagy } \\
\text { büntetés }\end{array}$ & $\begin{array}{l}\text { Önkont- } \\
\text { roll } \\
\text { Az én } \\
\text { bevonása } \\
\text { Belső } \\
\text { jutalom és } \\
\text { büntetés }\end{array}$ & $\begin{array}{l}\text { Személyes } \\
\text { érdeklődés } \\
\text { Tudatos } \\
\text { értékelő } \\
\text { aktivitás }\end{array}$ & $\begin{array}{l}\text { Egyetértés } \\
\text { tudatosság } \\
\text { személyes } \\
\text { azonosulás }\end{array}$ & $\begin{array}{l}\text { Belső } \\
\text { megelége- } \\
\text { dettség } \\
\text { önmegva- } \\
\text { lósítás }\end{array}$ \\
\hline $\begin{array}{c}\text { A zenei } \\
\text { gyakorlat } \\
\text { szempontjá- } \\
\text { ból releváns } \\
\text { viselkedés }\end{array}$ & $\begin{array}{l}\text { „Nem aka- } \\
\text { rok gyako- } \\
\text { rolni." }\end{array}$ & $\begin{array}{l}\text { "Bajba ke- } \\
\text { rülök, ha } \\
\text { nem gya- } \\
\text { korlok." }\end{array}$ & $\begin{array}{l}\text { „Büszke } \\
\text { vagyok } \\
\text { magamra, } \\
\text { ha gyakor- } \\
\text { lok” }\end{array}$ & $\begin{array}{l}\text { „Fontos } \\
\text { számomra } \\
\text { a gyakor- } \\
\text { lás." }\end{array}$ & $\begin{array}{l}\text { "Azért } \\
\text { gyakorlok, } \\
\text { mert a } \\
\text { zene a leg- } \\
\text { fontosabb } \\
\text { dolog az } \\
\text { életemben" }\end{array}$ & $\begin{array}{l}\text { "Amikor } \\
\text { hangsze- } \\
\text { ren játszok } \\
\text { elveszek a } \\
\text { pillanat- } \\
\text { ban" }\end{array}$ \\
\hline
\end{tabular}

A három pszichológiai szükséglet, az autonómia, a kompetencia és a társas kapcsolatok nagyobb mértékű teljesülését tapasztalták azoknál a tanulóknál, akik intenzíven részt vettek a zenetanulás folyamatában. Ezzel szemben ezeknek a szükségleteknek az alacsony szintje volt jellemző akkor, amikor a hangszertanulás abbahagyása mellett döntöttek (Evans et al., 2013). Ezen motivációs tényezők hiánya lemorzsolódáshoz vezethet, ami egyidejüleg csalódást okozhat a szülő 
számára is (Comeau et al., 2019). A tanulók motivációját kezdetben meghatározhatja a szülő, valamint a tevékenység újszerüsége. A kezdeti izgalom, lelkesedés elmúlása után sok gyermek elveszíti a kedvét, hiszen a hangszertanulás sok időt és erőfeszítést igényel (McPherson, 2000). Egyes tanulók megtartják a nagymértékủ autonóm motivációt, ugyanakkor sokan feladják a motiváció hiánya miatt (Renwick \& McPherson, 2009; Comeau et al., 2019).

Az öndeterminációs elmélet szerint olyan környezetre van szükség, amely támogatja a három szükséglet kielégítését. Az autonóm motiváció a kitartás, önirányítás, önjutalmazás és a fejlődési lehetőségek belső törekvését eredményezi. Ha a környezet a tanuló számára csalódást okoz pszichológiai igényeinek kielégítésében, akkor a motiváció erőssége csökken. Hiányzik a személyes törekvés, a fejlődés és a jóllét. Ilyenkor a motivációt a külső jutalmak tartják fent, nem pedig az érdeklődés vagy a személyes törekvés, hiszen az a környezet nem illeszkedik személyes értékekhez (Ryan \& Deci, 2017; Freer \& Evans, 2019).

Comeau és munkatársai (2019) az öndeterminációs elmélet alapján alakították ki kérdöívüket, amelyet kutatásunkhoz magyarra fordítottunk. A kérdőív kidolgozása előtt a szerzők fókuszcsoportos interjút végeztek diákok, pedagógusok és szülők bevonásával. A motiválatlanságnál a szándék és az érdeklődés hiányára utaló állítások, a külső szabályozásnál a szülők és a pedagógusok és a büntetés jelennek meg a kérdőívben. Az introjekció esetén a belső szorongásra és a belső kontrollra épülnek az állítások. Az azonosulásnál és integrációnál az értékké válás, a szakmaiság jelenik meg, az intrinzik motivációnál pedig az érdeklődés és az élvezet.

\section{Zeneoktatás a hazai közoktatásban}

Egy hangszer elsajátítása történhet iskolai keretek között, magántanárok által, illetve teljesen önképző módon is. Pontos hazai adatok nincsenek arról, hogy hányan tanulnak a különböző képzési módokon (Szabó, 2021). A zenetanulás intézményi hátterét két részre oszthatjuk: beszélhetünk kötelező iskolai és szabadon választott zenei oktatásról. A kötelező zenetanulás az ének-zene tanórán megvalósuló zeneoktatás, amely leginkább az éneklésre irányul, a hangszertanulás itt nem kap jelentős szerepet. A zeneiskolai tanulás nem kötelező, a hangszeroktatás elsősorban ezekben az intézményekben folyik. A zeneiskolák speciális helyet foglalnak el a közoktatásban. A törvényi meghatározás szerint „Az alapfokú művészeti iskola feladata, hogy kibontakoztassa a müvészi képességeket, fejlessze a művészi tehetségeket, igény esetén felkészítsen szakirányú továbbtanulásra" (2011. évi CXC. 16. $\mathbb{S}(1)$ ). Az oktatásban nem kötelező részt venni, emellett tandíjhoz kötött. Minden felvételt nyert diák azonos összegü tandíjat fizet, a felsőbbévesek számára viszont a tanulmányi átlaghoz kötik a tandíjat. A zenemüvészeti szakgimnáziumok a képzés következő szintje, mely összekötésként funkciónál az alapképzés és a zeneművészeti felsőoktatás között (Héjja, 2016). A 2015. évi 
LXV. törvény a nemzeti köznevelésről szóló 2011. évi CXC. törvény alapján a szakközépiskolák átalakultak szakgimnáziumokká (Héjja, 2016, 2018). Ezek célja elsősorban a szakmára, hivatásra nevelés. A képzésben való részvétel feltétele az alkalmassági vizsga, amely intézményenként eltérő lehet (Héjja, 2018). A szakgimnázium ötéves képzés, melyben közismereti és szakmai képzés is folyik (2011. évi CXC. 12. $\mathbb{S}(1)$ ).

A zeneiskolába és a zenemüvészeti szakgimnáziumokba jelentkezők - jó esetben - érdeklődést mutatnak a hangszertanulás és a klasszikus zene iránt. Fontos, hogy a hangszer elsajátítása során milyen mértékben van jelen az intrinzik motiváció, a flow, hogyan viszonyulnak a kihívást jelentő feladatokhoz, megfelelő célokat tűznek ki a tanulás és a gyakorlás során egyaránt, kapnak-e pozitív visszajelzést. Ezen tényezők hozzájárulnak az intrinzik motiváció fenntartásához (Janurik \& Józsa, 2018).

Hallam és munkatársai (2020) kutatása szerint a hangszertanulással eltöltött idő előrehaladtával a zenetanulási motiváció nő a nem kötelező oktatás keretei között. Ezzel szemben a hazai közoktatásban az iskolai ének-zene óra a tanulók által legkevésbé kedvelt tantárgyak közé tartozik, emiatt több vizsgálat helyezte az ének-zene órához kapcsolódó motivációt a kutatás fókuszába. Janurik Márta és Józsa Krisztián (2018) hetedik évfolyamos tanulók motiváltságát, a különböző tanórai tevékenységek kedveltségét és a zenei énképet vizsgálta. Jakobicz Dorottya és munkatársai (2018) az iskolai ének-zene órák kedveltségének növelési lehetőségét elemezte a tanítási módszerek megváltoztatásával. Az általuk használt módszerek, mint a projektmódszer, a kooperatív tanulás, a drámapedagógiai módszerek, valamint a problémaalapú tanulás eredményesnek bizonyultak a motiváció erősítése terén. A digitális eszközök, mint például a Zenesziget applikáció ugyancsak erősítik a tanulók motivációját (Szabó, 2018a, 2018b). Pintér Tünde és Csíkos Csaba (2020) tanulmánya az iskolai zenei nevelés célját és feladatát vizsgálja a tanulók, szülők és tanárok megítélése alapján. A nemzetközi szakirodalom alapján is azt látjuk, hogy a zenetanulás kötelező iskolai keretek között nem a legkedveltebb tevékenység. A diákok szívesebben vesznek részt az iskolai tantervben elöírt többi tantárgyban, így például a nyelv, matematika, természettudományok vagy testnevelés. Ennek oka lehet például az, hogy mennyire érzik szükségesnek, fontosnak a jövőbeni céljaikhoz, továbbtanulásukhoz (McPherson \& O’Neill, 2010).

Szende Ottó (2000) a zenetanulási megkezdéséhez kapcsolódóan négy fó okot, tényezőt emel ki: 1. A tanulók önként, saját belső indíttatásból dönt a tanulás mellett, mert hallotta valahol a hangszert, 2 . vagy mert hallotta iskolatársát játszani és megtetszett neki. 3. A szülő kezdeményezi a tanulás elkezdését, mert szerinte gyermekének jó hallása van, könnyen megjegyzi a dalokat. 4. A szülő a gyermeket akarata ellenére íratja be a hangszertanulásra. A szerző problémaként említi, hogy bizonyos esetekben a hangszerválasztásnál nem veszik figyelembe a gyermek szándékát, ami a motiváció csökkenését okozhatja. Tanulmányában javaslatként fogalmazza meg, hogy a felvételi vizsgák során a gyermek hangszertanulási motivációjával is foglalkozzanak. 


\section{Zenetanulást befolyásoló tényezők}

Mint minden tanulási folyamat esetén, a zenei megismerés során is a környezetből érkező, extrinzik motívumok és a belső ösztönzésből fakadó, intrinzik motívumok együttesen határozzák meg az elsajátítás eredményességét. A fejlett tanulási motívumrendszer többkomponensü és nem csak egy-egy motívum kap szerepet a viselkedés alakításában (Józsa \& Fazekasné Fenyvesi, 2007). A külső és belső ösztönzők aránya változó a tanulási folyamat egyes fázisaiban, de fontos kiemelni, hogy a belső ösztönzés nagyobb hangsúlyt kap például a hangszerjáték elsajátítása során, ami folyamatos, kitartó és gyakori erőfeszítést igényel (Dohány, 2009). Ennek következtében az idő előrehaladtával nő a szerepe az önjutalmazó motívumoknak, ezáltal a tevékenységben lelt öröm élménye lesz az a mozgatóerő, ami újabb tevékenység végzésére késztet (Kiyoshi \& Csíkszentmihályi, 1998).

Sloboda (2001) az Egyesült Királyságban végzett kutatást azzal kapcsolatban, hogy a diákok miért hagyják abba a hangszertanulást. A brit zeneoktatás rendszere jelentősen eltér a magyartól, megállapításai ennek ellenére hasznosak a hazai helyzet elemzése során is. Angliában a kötelező tantárgy része a hangszeres képzés és a hangszerekkel való megismerkedés. Sok tanuló szerint a zenei képzés a többi tantárgyhoz képes kevésbé fontos, mert nem lesz a hangszertanulással később semmilyen céljuk sem. A kutatásban két tanulóval készült interjú eredményeivel szemlélteti a hangszertanulás kezdeti lelkesedését, valamint a felmerülő okokat, amiért abbahagyják a tanulmányaikat. A tanulóktól megkérdezték, mit jelent számukra a zenélés. Mary, az egyik tanuló szerint lehetőség a gyakorlásra, a hangszerjáték szeretete és mivel az osztályában sokan játszanak valamilyen hangszeren így úgy gondolta szórakoztató lesz. Lucy, a másik a tanuló szerint szórakoztató, élvezetes és hobbi elfoglaltság a zenetanulás. Sloboda (2001) kitért az osztályzatok, a nehéz darabok, a mások előtti fellépés szerepére, valamint a szülők és a pedagógusok támogatásának a fontosságára. A tantárgy 14 éves korig kötelező, utána szabadon választható, így felmérte azt is, hogy később fognak-e hangszeren játszani. További öt tényező jelent meg az interjúk során. Az egyik az, hogy a hangszertanulás unalmassá vált a diákok számára. Nem szerették a gyakorlást és más tevékenység fontosabbá vált számukra, mint a zenélés. Például más tantárgyakra való készülés, házi feladatok elvégzése és a barátaikkal való kapcsolattartás. Az autonómia támogatása ugyanakkor nagyon fontosnak mutatkozott. A tanulók válaszaiban megjelent, hogy a szülők nem kényszerítették, hanem támogatták, hogy olyan tevékenységeket folytassanak, amelyeket szeretnek. Ugyanakkor felügyelik és segítik a gyermekeik gyakorlását. A pedagógus-diák kapcsolat is meghatározó. Fontos szerepe van annak is, hogy miként tekintenek a tanulók a hangszertanulásra. A hobbi, a szabadidős tevékenységek a gyerekeknél még gyorsan változnak, cserélődnek (Sloboda, 2001).

A motiváció szempontjából különösen fontos megemlíteni a zenei énképet, hiszen a diákok kitartásában meghatározó. Janurik és munkatársai 
(2020) hetedikes diákok körében végeztek énképre vonatkozó vizsgálatot. Eredményeik szerint a zenei énkép formálódásában több tényező játszik szerepet: a zenei képességek, a zenei észlelés és az éneklés fejlettségének az önmegítélése, illetve hogy mennyire van jelen a zenei fejlődés lehetősége az ének-zene órán. Emellett a zenei énkép alakulásában szerepe van az otthoni mintának, értékeknek, a szülők zenei érdeklődésnek, az otthoni hangszerjátéknak és éneklésnek.

\section{Szülök és pedagógusok szerepe}

A zenehallgatási szokásainkat, a zenélésben való bekapcsolódásunkat jelentősen befolyásolja a bennünket körülvevő társas környezet (Janurik \& Józsa, 2018). A szülők támogatása pozitívan hat a gyermek zenei fejlődésre (Macmilian, 2004; Sichivitsa, 2007; McPherson, 2009). Creech (2001) a hegedün játszó gyermekeket vizsgálta, eredményei szerint a szülőknek az jelentette a legnagyobb kihívást, hogy magas szintű támogatást biztosítsanak gyermeküknek a tanulási folyamat kezdeti szakaszában, majd fenn tudják tartani ezt a támogató, ugyanakkor kihívást jelentő környezetet, amelyben a gyermek megtalálja a belső motivációt. A szülők zenei támogatása többek között abban nyilvánult meg, hogy maguk is hangszeren játszanak, zenét hallgatnak és a gyerekek tanulmányait úgy is segítik, hogy beszélgetnek a zenéről, eljárnak a fellépéseire (Sichivitsa, 2007). A szülői tevékenységet két különböző részre bonthatjuk: a szülői stílusra és a szülői gyakorlatra. A szülői stílus magában foglalja a gyermekhez füződő attitűdöket, létrehozva a támogató érzelmi légkört. A szülői gyakorlat pedig a konkrét viselkedéshez kapcsolódik. A szülői hozzáállás meghatározza, hogy milyen mértékben képesek kialakítani a gyermek számára azt az érzelmi klímát, ami elősegíti a hatékony zenei tanulást (McPherson, 2009). Azok a szülők, akik rendelkeznek zenei ismeretekkel és érdeklődnek a zene iránt, a gyermekeik számára általában át tudják adni ezeket az értékeket (Hallam et al., 2016).

Ahhoz, hogy a zenetanulás élménnyé váljon a diákok számára, szükség van a támogató szülői környezetre. A Felelős Szülők Iskolája (2017) weboldal néhány hasznos tanácsot fogalmaz meg a gyerekek ösztönzésével kapcsolatban. Szerintük az egyik legfontosabb a megfelelő hangszer kiválasztása. A hangszerek kipróbálása és megismerése által olyan hangszer választható, amely leginkább illik a tanulók személyiségéhez. Ellenkező esetben frusztrációt válthat ki, amely később lemorzsolódáshoz vezet. A tanulás folyamatában a gyakorlás támogatása és figyelemmel kísérése elengedhetetlen. Például érdeklődik a szülő azzal kapcsolatban, hogy mit gyakorol, ha esetleg elakadt, hogyan tud segíteni. A zenéről való beszélgetés is fenntarthatja az érdeklődést, ha megkérdezzük melyik a kedvenc daluk, mit szeretnek legjobban a zenetanulásban. Ha a gyerekek érzik a szülők rájuk irányuló figyelmét, ha eljárnak a fellépéseikre vagy ha az otthoni gyakorlást meghallgatják, akkor az szintén ösztönzően hat, ezáltal több időt fordítanak a gyermekek a hang- 
szer gyakorlására. A szülők mellett a pedagógus szerepe is meghatározó. A megfelelő technikák és változatos tanítási módszerek alkalmazása, a bátorító és támogató légkör kialakítása hozzájárul a motiváció fenntartásához. A klasszikus és az érdeklődésnek megfelelő darabok kiválasztásának egyensúlya segíti a különböző zenei típusok megismerését. Egy hangszer elsajátítása sok időt és erőfeszítést igényel, és a tanulási folyamat során kudarc is érheti a gyermeket, ilyenkor különösen fontos a bíztatás és a segítség. Az öndeterminációs elmélet alapján az autonómiát támogató szülői nevelés során lehetővé teszik a gyermekek számára, hogy az őket érintő kérdésekbe beleszóljanak, választási lehetőséget biztosítanak, és ösztönözik is erre a gyermekeiket. A támogató környezet megteremtése által a gyermekek intrinzik módon motiváltabbak leszek. Ezzel szemben az erősebb szülő kontroll alacsonyabb önértékeléshez és szorongáshoz vezethet (Józsa et al., 2019; Grolnick et al., 2021). A szülők jelentős szerepe mellett a testvérek, rokonok, barátok hatása is különösen fontos, föként a kisebb gyerekek esetében (Contero \& JausetBerrocal, 2017).

Susan Hallam (2002) szerint a zenei motiváció kutatásának többsége a család és kisebb mértékben a tanár hatására összpontosítanak. A szülők mellett Anguiano (2006) szerint a pedagógusok által támogatott autonómia is meghatározó. Degner és munkatársai (2003) szerint a jó pedagógus konkrét célokat tűz ki, visszajelzést ad a tanulók számára, valamit, ha hibáznak, akkor lehetőséget biztosít a javításra. A diákok számára a stresszes és kihívást jelentő helyzetre való felkészítést támogatja (McPherson \& McCormick, 2006), továbbá fejleszti a tanulók önhatékonyságát (Mitchell \& DellaMattera, 2010; Längler et al., 2018). A pedagógusok számára az érdeklődés felkeltése és fenntartása jelenti a legnagyobb kihívást, hiszen az alkalmazott módszerek nem feltétlenül nyújtanak lehetőséget az örömteli zenélésnek, amely által a tanulók elsajátíthatják azokat a zenei készségeket és képességeket, amelyek szükségesek az egyes zenei műfajokat értelmezéséhez és élvezetéhez (Janurik \& Józsa, 2018). Ho (2011) a hangszertanulás és a gyakorlás kapcsolatát vizsgálta, eredményei szerint a gyakorlás iránti motivációban, valamint a zenei karrier építéshez füződő célok elérésében a pedagógusoknak nagyobb szerepe van, mint a szülőknek.

\section{Fiúk, lányok és hangszerek}

A hangszeres tanulmányokban a fiúk aránya világszerte kisebb, mint a lányoké. A lányok az iskolai zenei teszteken általában jobban teljesítenek (Hallam, 2004). A kutatások szerint a lányok hatékonyabb stratégiákat alkalmaznak a gyakorlás során, és szívesen vesznek részt olyan foglalkozáson, ahol tudásuk fejlődhet és mások előadását figyelhetik meg (Szabó, 2021). A fiúk esetében akkor nagyobb a zene iránti érdeklődés, ha a technológiához és zenetechnikához kötődik, ebben az esetben pozitívabb attitüd jelenik meg és magabiztosabbak, mint a lányok (Hallam et al., 2008). 
A sztereotípiáknak is nagy szerepe van a diákok hangszertanulása során. McPherson és munkatársai (2016) szerint a hangszer kiválasztásának módját befolyásolja a hangszer kinézete, az általa létrehozott hang. A sztereotípiák abban nyilvánulnak meg, hogy a lányok legtöbbször a kisebb és magasabb hangú hangszert részesítik előnyben. Hallam és munkatársai (2008) tanulmányában a szülők véleményét is befolyásolják a mindennapokban megjelenő sztereotípiák, így a lányok számára általában a hegedűt, a fuvolát és a klarinétot választják, míg a fiúknak a dobot, a trombitát és a harsonát. A hangszer kiválasztása során a diákok az általuk kedvelt előadó vagy példakép, vagy a barátaik által játszott hangszerek mintája alapján döntenek egy hangszer mellett (McPherson et al., 2016). A gyakorlás megítélésével kapcsolatban is eltérés mutatkozik. A lányokra általában nagyobb hatással vannak a pedagógusok és a szülők, míg a fiúkat általában a barátaik befolyásolják, ugyanakkor Hallam (2013) vizsgálatából kiderül, hogy a klasszikus hangszeren játszó fiúk nagyobb mértékü szülői támogatásról számoltak be (Hallam et al., 2017). Contero és Jauset-Berrocal (2017) szerint a legkedveltebb vagy legtöbbet választott hangszertípus a vonós, majd a fúvós, végül az ütős hangszerek. A különböző hangszertípusokra vonatkozó kutatások főleg a gyakorlásra, a gyakorlással töltött időre fókuszálnak.

A hangszerek kiválasztásánál több szempontot is figyelembe kell venni. Az erre vonatkozó kutatások alapján általánosságban elmondható, hogy a tanulók környezete (szülők, pedagógusok és társak), a hangszer nehézsége és elérhetősége, a hangszer mérete a hangzása és a nemi sztereotípiák is befolyásolja a választást. Egyes hangszerek preferálásának oka lehet a kiadott hang és hangszín (Bayley, 2004). További szempont lehet az is, ha tudjuk, hogy milyen zenét szeret hallgatni és így pozitívan viszonyul a dal eljátszásához. Fontos, hogy hol tud gyakorolni, van-e elég hely, mennyit tud gyakorolni, hiszen hangszerenként eltérő mennyiségű tanulási idő szükséges ahhoz, hogy valaki profi zenésszé váljon. Ha a diáknak több segítségre van szüksége, akkor mennyire könnyü magántanárt találni. További szempont lehet az anyagi lehetőség is, a gyermekek fizikai korlátai. A hangszerek kiválasztásánál a személyiség is meghatározó, hiszen egy hangszer lehet „magányos”, mint a zongora vagy inkább „társasági” (Szivárványzene, 2013).

\section{Kutatási célok és módszerek}

\section{A vizsgálat célkitüzése}

Tanulmányuk célja az, hogy megismerjük a hangszeren tanuló diákok motivációját az öndeterminációs elméleten alapuló elméleti modell alapján. Célunk továbbá, hogy elemezzük néhány háttérváltozó (tanulói autonómia, tanulással eltöltött idő, hangszertípus, nem, iskolai tantárgyi attitűdök) kapcsolatát a hangszertanulási motivációval. 


\section{A vizsgálat mintája}

Az adatfelvétel online formában, Google-kérdőívvel történt 2021 februárjában. A kérdőívet 151 hangszeren tanuló, 10 és 18 év közötti diák töltötte ki anonim módon, 100 lány és 51 fiú. A diákok közül 68 tanuló alapfokú, 70 tanuló középfokú mủvészetoktatásban vesz részt. 13 tanuló a közoktatási rendszeren kívül tanul hangszeren játszani. A tanulók a következő hangszereken játszanak: fúvós hangszeren 53 , vonós hangszeren 26 , pengetős hangszeren 33, billentyüs hangszeren 35 és ütős hangszeren 4 tanuló. (2. táblázat)

\section{2. táblázat}

A diákok csoportosítása az általuk tanult hangszerek alapján

\begin{tabular}{|c|c|c|c|c|}
\hline \multicolumn{5}{|c|}{ Hangszercsoportok } \\
\hline $\begin{array}{l}\text { Fúvós } \\
(\mathrm{N}=53)\end{array}$ & $\begin{array}{l}\text { Vonós } \\
(\mathrm{N}=26)\end{array}$ & $\begin{array}{c}\text { Pengetős } \\
(\mathrm{N}=33)\end{array}$ & $\begin{array}{l}\text { Billentyüs } \\
(\mathrm{N}=35)\end{array}$ & $\begin{array}{l}\text { Ütős } \\
(\mathrm{N}=4)\end{array}$ \\
\hline $\begin{array}{l}\text { fagott } \\
\text { furulya } \\
\text { fuvola } \\
\text { harsona } \\
\text { klarinét } \\
\text { kürt, vadászkürt } \\
\text { oboa } \\
\text { szaxofon } \\
\text { trombita } \\
\text { trombita }\end{array}$ & $\begin{array}{l}\text { brácsa } \\
\text { cselló } \\
\text { hegedű }\end{array}$ & $\begin{array}{l}\text { citera } \\
\text { gitár } \\
\text { hárfa }\end{array}$ & $\begin{array}{l}\text { csembaló } \\
\text { orgona } \\
\text { zongora }\end{array}$ & dob \\
\hline
\end{tabular}

A diákok 7\%-a idén vagy egy éve kezdett hangszeren játszani, 15\% már kéthárom éve tanul hangszeren, 16\% négy-öt éve, 13\% hat éve tanul és a legnagyobb arányban, $49 \%$ tanul több mint hat éve valamilyen hangszeren.

\section{A vizsgálat méröeszköze}

A vizsgálathoz Comeau, Huta, Lu és Swirp (2019) hangszertanulási motiváció kérdőívét (Motivation for Learning Music, MLM) adaptáltuk magyarra. Vizsgálatunk a kérdőív első magyar alkalmazása. A 3. táblázatban látható az MLM-kérdőív szerkezeti felépítése, amely összesen 25 tételt tartalmaz öt faktorba rendezve. Az egyes faktorok értelmezése a következő: A motiválatlanság a motiváció hiányát jelenti. A külső szabályozás során a cselekvés egy jutalom elérése vagy a büntetés elkerülése érdekében történik. Az introjekció működése hasonló, mint a külső szabályozás, de a nyomást a szorongás, önértékelés váltja ki. Az azonosulás/integráció során tudatos értékelés, egyéni szándék jelenik meg. Az intrinzik motiváció és az integrált motiváció között az a különbség, hogy az intrinzik motiváció az élvezeten és az érdeklődésen alapszik, míg az integrált az értékérzeten. Ez azt jelenti, hogy bár nem feltétlenül élvezetes az adott tevékenység, de fontos számára. Ez az öt faktor folytonosságot képvisel a zenetanulás iránti motiválatlanság 
és az önjutalmazó módon motivált zenetanulás között (Renwick \& Reeve, 2012; Evans, 2015).

A hangszertanulási motiváció kérdőív után a tanulók egy rövid háttérkérdőívet is kitöltöttek.

\section{3. táblázat}

A hangszertanulási motiváció kérdőív szerkezete és példatételei

\begin{tabular}{|l|c|c|}
\hline \multicolumn{1}{|c|}{ Faktorok } & Tételek száma & Példák \\
\hline Motiválatlanság & 5 & Tanulok egy hangszeren... \\
\hline Külső szabályozás & 5 & de időpocsékolásnak tartom. \\
\hline Introjekció & 5 & $\begin{array}{c}\text { mert szüleim csalódottak lennének, ha } \\
\text { abbahagynám. }\end{array}$ \\
\hline Azonosulás és integráció & 5 & mert zenész akarok lenni. \\
\hline Intrinzik motiváció & 5 & mert jól érzem magam mám tỏle. \\
\hline
\end{tabular}

Megjegyzés: Minden skálából példaként egy-egy állitást közlünk. Az állitásokat ötfokú skálán értékelték a tanulók.

\section{Eredmények}

\section{Pszichometriai mutatók és leíró statisztika}

A pszichometriai mutatók részleteit egy másik tanulmányban tesszük közzé (Földi \& Józsa, megj. alatt), itt csak röviden összegezzük azokat. Megerősítő faktoranalízist végeztünk annak igazolására, hogy az elméleti modell megfelelően illeszkedik az adatainkra. Az illeszkedési mutatókat a 4. táblázatban foglaltuk össze. Ez alapján megállapítható, hogy a kérdőív magyar változatának a faktoriális validitása megfelelő, az MLM-kérdőív öt faktorból álló modellje a hazai mintán is igazolást nyert.

\section{4. táblázat}

A hangszertanulási motiváció kérdöív illeszkedési mutatói

\begin{tabular}{|l|c|c|c|c|c|c|c|}
\hline & \multicolumn{1}{|c|}{$\mathbf{X}^{2}$} & df & \multicolumn{1}{c|}{$\mathbf{p}$} & CFI & TLI & RMSEA & SRMR \\
\hline $\begin{array}{l}5 \text { fakto- } \\
\text { ros mo- } \\
\text { dell }\end{array}$ & 659 & 265 & $<0,001$ & 0,836 & 0,814 & 0,099 & 0,088 \\
\hline
\end{tabular}

Megjegyzés: df: szabadságfok, CFI: Comparative Fit Index; TLI: Tucker-Lewis Index; RMSEA: Root-Mean-Square Error of Approximation, SRMR: Standardized Square Root Mean Residual 
Az 5. táblázat közli a kérdőív skáláihoz tartozó Cronbach- $\alpha$ reliabilitásokat, valamint a skálák átlagait és szórásait. Az eredmények alapján elmondható, hogy az egyes faktorok és a teljes mérőeszköz megbízhatósága a magyar minta esetében is megfelelö. Az 1. táblázatban bemutattuk, hogy az MLMkérdőív öt faktora - elméleti feltevések alapján - miként rendeződik átlag szerint növekvő sorba a teljes motiválatlanságtól az önjutalmazó motivációig. E modell megerősítését adja, hogy vizsgálatunkban az öt faktorhoz tartozó átlagok a sorba rendezettségnek megfelelően egyre nagyobbak. A faktorok átlagai közötti különbségek szignifikánsak (Mauchly's teszt, $\chi^{2}(9)=116,9$, $\mathrm{p}<0,01$, Greenhouse-Geisser utóelemzés $\mathrm{F}(3,450)=302,5$, $\mathrm{p}<0,01)$. Mintánkat a motiválatlanság skála alacsony értéke, míg az intrinzik motiváció magas értéke, továbbá a közbülső faktorok is azt mutatják, hogy a hangszeres zenét tanuló diákokat a mintánkban erős motiváltság jellemzi.

\section{5. táblázat}

A hangszertanulási motiváció kérdőív skáláinak megbizhatósági mutatói, átlagai és szórásai

\begin{tabular}{|l|c|c|c|c|}
\hline \multicolumn{1}{|c|}{ Faktorok } & Cronbach- $\boldsymbol{\alpha}$ & Tételek száma & Átlag & Szórás \\
\hline Motiválatlanság & 0,79 & 5 & 1,45 & 0,70 \\
\hline Külső szabályozás & 0,80 & 5 & 2,15 & 1,00 \\
\hline Introjekció & 0,84 & 5 & 2,88 & 1,19 \\
\hline Azonosulás & 0,88 & 5 & 3,41 & 1,18 \\
\hline Intrinzik motiváció & 0,82 & 5 & 4,64 & 0,52 \\
\hline
\end{tabular}

\section{A motivációfaktorok összefüggései}

A 6. táblázat mutatja a motiváció faktorok közötti összefüggéseket. A faktorok között pozitív és negatív korrelációkat is kaptunk. A motiválatlanság és a külső szabályozás által létrejövő hangszertanulás között szignifikáns pozitív korrelációt kaptunk. Az introjekcióval ezeknek a faktoroknak nincs összefüggése. Az extrinzik motiváció, az introjekció és az azonosulás külső szabályozás, amely az öndeterminációs elmélet alapján egy kontinuum mentén helyezkedik el, ahogyan a tanulás, cselekvés egyre önállóbbá válik. Az azonosulás hasonló, mint az intrinzik motiváció, így magas is az összefüggés közöttük. A motiválatlanság és az intrinzik motiváció közötti negatív korreláció jól magyarázható az elmélettel, hiszen minél nagyobb belső motiváltság jellemzi a tanulókat annál kevésbé igaz rájuk a motiválatlanság. A külső szabályozás és az intrinzik motiváció közötti negatív korreláció azzal magyarázható, hogy a külső kontroll csökkentheti az intrinzik motivációt (Ryan \& Deci, 2017). Az elmélet alapján arról beszélhetünk, hogy az adott tevékenység dominánsan kívülről vagy belülről, saját akarat által irányított. A külső és belső szabályozás befolyásolja a zenetanulási hajlandóságot. A viselkedés értelmezése során azonban a külső és belső szabályozást nem szabad külön- 
külön értelmezni, hiszen a cselekedetek összetettek. Ha egy tanuló erősen motivált egy tevékenységre, akkor extrinzik és intrinzik motívumok egyidejüleg befolyásolják (Ryan \& Deci, 2017; MacIntyre et al., 2018).

\section{6. táblázat}

Motivációs típusok közötti korrelációk

\begin{tabular}{|l|c|c|c|c|c|}
\hline & $\begin{array}{c}\text { Motiválat- } \\
\text { lanság }\end{array}$ & $\begin{array}{c}\text { Extrinzik } \\
\text { motiváció }\end{array}$ & Introjekció & $\begin{array}{c}\text { Azonosu- } \\
\text { lás }\end{array}$ & $\begin{array}{c}\text { Intrinzik } \\
\text { motiváció }\end{array}$ \\
\hline Motiválatlanság & &, $21^{*}$ &,- 09 &,$- 41^{* * *}$ &,$- 49^{* * *}$ \\
\hline Külső szabályozás & & &, $60^{* * *}$ &, $16^{*}$ &,$- 21^{*}$ \\
\hline Introjekció & & & &, $43^{* * *}$ &, $22^{* *}$ \\
\hline Azonosulás & & & & &, $46^{* * *}$ \\
\hline Intrinzik motiváció & & & & & \\
\hline
\end{tabular}

Megjegyzés: ***p<0,01; *0,05

Comeau és munkatársai (2019) eredményeivel összehasonlítva a motiválatlanság három motivációs típussal, az introjekcióval, az azonosulással és az intrinzik motivációval való összefüggése teljes mértékben megegyezik az általunk kapott eredményekkel. A legnagyobb különbséget a két mérés között a motiválatlanság és a külső szabályozás közötti korrelációban találtuk. Az eredeti kutatásban a két típus között szorosabb összefüggést találtak $(\mathrm{r}=0,40 ; \mathrm{p}<0,01)$. A másik különbséget az azonosulás és az introjekció között találtuk, ahol a mi adataink között volt erősebb összefüggés, mint az eredeti kutatásban $(\mathrm{r}=0,24 ; \mathrm{p}<0,01)$. Az azonosulás és a külső szabályozás között szignifikáns összefüggést találtunk, ugyanakkor Comeau és munkatársai (2019) eredményei között nem volt szignifikáns korreláció ( $\mathrm{r}=-0,06 ; \mathrm{p}>0,05)$.

\section{Egyéni vagy szülöi döntés}

Az autonómiát támogató szülők lehetőséget biztosítanak gyermekeik számára, hogy az őket érintő kérdésekben döntsenek. Ilyen döntés az is, hogy tanul-e hangszeren a gyermekük. Az öndetermináció elmélet alapján a gyermekek motiváltabbak, ha az autonómiára való törekvésüket a szüleik támogatják (Grolnick et al., 2021). Az eredményeink alátámasztják ezt. Azoknak a diákoknak, akik önállóan döntöttek a hangszertanulás mellett, erősebb az intrinzik motivációjuk (Cohen-d=0,39). Ezzel szemben azok a diákok, akik szülői kontroll által hozták meg döntésüket jellemzően motiválatlanabbak (Cohen- $\mathrm{d}=0,38)$, lásd 7. táblázat. A külső szabályozás, az introjekció és az azonosulás esetében nincs szignifikáns különbség a két csoport között. 


\section{7. táblázat}

Hangszertanulás melletti döntés és a motivációs típusok

\begin{tabular}{|c|c|c|c|c|c|c|c|c|}
\hline & \multicolumn{4}{|c|}{ Hangszertanulás döntése } & \multicolumn{2}{|c|}{ Levene-teszt } & \multicolumn{2}{|c|}{$\begin{array}{l}\text { Kétmintás } \\
\text { t-próba }\end{array}$} \\
\hline & \multicolumn{2}{|c|}{$\begin{array}{l}\text { Önállóan } \\
\text { N=66 }\end{array}$} & \multicolumn{2}{|c|}{$\begin{array}{c}\text { Szülővel } \\
\text { N=85 }\end{array}$} & \multirow[t]{2}{*}{$\mathbf{F}$} & \multirow[t]{2}{*}{$\mathbf{p}$} & \multirow[t]{2}{*}{$\mathbf{t}$} & \multirow[t]{2}{*}{$\mathbf{p}$} \\
\hline & $\mathbf{M}$ & SD & $\mathbf{M}$ & SD & & & & \\
\hline Motiválatlanság & 1,31 & 0,66 & 1,57 & 0,71 & 5,68 & $<0,05$ & $-2,29$ & $<0,05$ \\
\hline Külső szabályozás & 2,03 & 1,07 & 2,24 & 0,94 & 2,90 & 0,09 & $-1,31$ & 0,19 \\
\hline Introjekció & 2,86 & 1,24 & 2,89 & 1,15 & 1,33 & 0,25 & $-0,17$ & 0,86 \\
\hline Azonosulás & 3,48 & 1,17 & 3,36 & 1,19 & 0,06 & 0,80 & 0,65 & 0,52 \\
\hline Intrinzik motiváció & 4,75 & 0,40 & 4,56 & 0,58 & 6,18 & $<0,05$ & 2,28 & $<0,05$ \\
\hline
\end{tabular}

\section{Hangszertípusok}

A különböző hangszertípusokon játszó diákokra vonatkozóan is megnéztük, van-e különbség a motivációjukban. Az ütős hangszeren játszók a kis elemszám (N=4) miatt nem kerültek bele az elemzésbe. Az eredmények alapján az azonosulás során szignifikáns különbség van a vonós hangszeren $(M=3,95$; $\mathrm{SD}=1,34)$ és a pengetős hangszeren $(\mathrm{M}=3,14 ; \mathrm{SD}=1,01)$ tanulók között, valamint a vonós hangszeren és a billentyüs hangszeren $(M=3,11 ; S D=1,07)$ játszók között $(\mathrm{F}=2,77, \mathrm{p}<0,05)$. Leginkább a vonós hangszeren játszók azonosulnak a hangszertanulással, ezt követően a fúvós hangszeren játszók, majd a pengetős és a billentyűs hangszeren játszók.

\section{Alapfokú és középfokú müvészetoktatásban részt vevö diákok közötti különbségek}

Megvizsgáltuk, hogy a művészetoktatásban részt vevő diákok zenetanulási motivációja eltér-e az alapfokon és a középfokon tanulók esetében. Az elemzés során két motivációs típus, az introjekció és az azonosulás jellemzőbb a középfokú oktatásban részt vevők diákokra, amit a 8 . táblázatban tüntettünk fel. Ennek oka az lehet, hogy minél több ideig tanulnak hangszeren játszani a diákok, annál motiváltabbak lesznek (lásd még Hallam et al., 2020). Az intrinzik motiváció esetében nem kaptunk szignifikáns különbséget. Fontos azonban megjegyezni, hogy ez már az alapfok esetében is magas volt, így a mérőeszköz plafoneffektusa miatt további növekedést nehéz már kimutatni. Az itt kapott eredményekkel szemben az iskolai tanórák során végzett kutatások azt mutatják, hogy az életkor előrehaladtával a tanulási motiváció az iskolában többnyire csökken (Józsa et al., 2020). 


\section{8. táblázat}

Alapfokú és középfokú oktatásban részt vevő diákok motivációja közötti különbségek

\begin{tabular}{|l|c|c|c|c|c|c|c|c|}
\hline \multirow{2}{*}{} & \multicolumn{4}{|c|}{ Iskolatípus } & \multicolumn{2}{c|}{ Levene-teszt } & \multicolumn{2}{c|}{$\begin{array}{c}\text { Kétmintás } \\
\text { t-próba }\end{array}$} \\
\cline { 2 - 9 } & \multicolumn{2}{|c|}{ Alapfok } & \multicolumn{2}{c|}{ Középfok } & \multirow{2}{*}{ F } & p & t & p \\
\cline { 2 - 10 } & M & SD & M & SD & & & & \\
\hline Motiválatlanság & 1,50 & 0,67 & 1,37 & 0,66 & 0,13 & 0,72 & $-1,09$ & 0,28 \\
\hline Külső szabályozás & 2,11 & 0,97 & 2,23 & 1,04 & 0,35 & 0,55 & 0,712 & 0,47 \\
\hline Introjekción & 2,62 & 1,13 & 3,13 & 1,19 & 1,52 & 0,22 & 2,57 & $<0,05$ \\
\hline Azonosulás & 2,90 & 1,05 & 4,01 & 1,01 & 0,67 & 0,41 & 6,34 & $<0,01$ \\
\hline Intrinzik motiváción & 4,58 & 0,53 & 4,71 & 0,501 & 0,94 & 0,33 & 1,44 & 0,15 \\
\hline
\end{tabular}

\section{Összefüggés az iskolai tantárgyi attitüdökkel}

Szakmailag érdekes és fontos felvetés lehet, hogy a hangszertanulás milyen kapcsolatban áll az iskolai tantárgyak kedvelésével, az iskolai tanulás szeretetével. Ezért a vizsgálat során arról is adatokat gyüjtöttünk, hogy a diákok mennyire kedvelik az egyes iskolai tantárgyakat. A hangszeres zenetanuláshoz az iskolai tantárgyak közül tartalmi szempontból az ének-zene tantárgy áll a legközelebb. Szignifikáns összefüggést csak a hangszertanulás iránti motiválatlanság és az ének-zene tantárgyi attitüd ( $r=-0,23, p<0,01)$ között kaptunk. Azaz, ha motiváltalan a tanuló a hangszeres zenetanulásra, akkor az iskolai ének-zene tantárgyat sem kedveli. A hangszertanulás iránti motiválatlanság ugyancsak negatív összefüggést mutat az irodalom $(r=-0,23, p<0,01)$, a történelem $(r=-0,21, p<0,01)$ és az idegennyelv attitüddel $(r=-0,21, p<0,05)$. A hangszertanulás iránti extrinzik motiváció szintén negatív kapcsolatban van a nyelvtan $(\mathrm{r}=-, 22, \mathrm{p}<0,01)$ és az idegennyelv $(\mathrm{r}=-0,23, \mathrm{p}<0,01)$ tantárgyak kedvelésével. A hangszertanulás iránti intrinzik motiváció ugyanakkor egyik iskolai tantárggyal sem mutat összefüggést.

Az ének-zene tantárgyi attitűd pozitív összefüggést mutat az irodalom $(\mathrm{r}=0,22, \mathrm{p}<0,01)$, a történelem $(\mathrm{r}=0,28, \mathrm{p}<0,01)$, az idegennyelv $(\mathrm{r}=0,32$, $\mathrm{p}<0,01)$, a rajz $(\mathrm{r}=0,43, \mathrm{p}<0,01)$, a biológia $(\mathrm{r}=0,29, \mathrm{p}<0,01)$ és a földrajz $(\mathrm{r}=0,32, \mathrm{p}<0,01)$ attitüdökkel. Azaz, ha az ének-zenét jobban kedveli a tanuló, akkor valószínü, hogy ezeket a tantárgyakat is.

Az előbbiekben csak a szignifikáns összefüggéseket közöltük. A nem közölt változók esetében nem volt összefüggés. Ezek a szignifikáns korrelációk csak gyenge összefüggésre utalnak. Az eredmények összefoglalóan azt mutatják, hogy a hangszertanulás iránti erős belső elköteleződésnek nincs kapcsolata az iskolában tanult tantárgyak szeretetével, még az ének-zene tantárgy kedvelésével sem. 


\section{Fiúk és lányok közötti különbségek}

A kapott eredmények alapján nincs szignifikáns különbség a fiúk és a lányok között a hangszertanulás iránti motiváltságban. A hangszertanulási motiváció vizsgált öt faktorának egyikében sem találtunk szignifikáns eltérést. Nincs szignifikáns különbség a fiúk és a lányok között az iskolai ének-zene tantárgyi attitüdben sem $(\mathrm{t}=0,38, \mathrm{p}=0,70)$. Eredményeinkkel összhangban, Hallam és munkatársai (2020) által végzett kutatásban sem mutattak ki szignifikáns eltérést a fiúk és a lányok motiváltsága között. A nemek közötti motivációs különbségekről azonban viszonylag kevés szakirodalmat találunk.

\section{Összefoglalás}

A nemzetközi kutatásokkal ellentétben a hazai zenepedagógia-kutatásokban a hangszeres zenetanulás és a tanulók motivációjának a kapcsolata kevéssé vizsgált terület. Tanulmányunk célja ezért a 10-18 éves, hangszeren tanuló diákok motivációjának megismerése volt. A kutatáshoz az öndeterminációs elmélet nyújtott elméleti keretet. Az adatgyüjtést egy magyarra adaptált kérdőív segítségével végeztünk. A tanulók online töltötték ki a 25 tételt tartalmazó kérdőívet, valamit egy háttérkérdőívet.

A kérdőív a pszichometriai mutatók alapján alkalmasnak bizonyult a hangszeren tanuló diákok motivációjának a vizsgálatára, megfelelő faktoriális validitást és reliabilitást kaptunk. Az adatok értelmezéséhez az elméleti modell ötfaktoros struktúráját alkalmaztuk. A motiváció faktorai között pozitív és negatív összefüggéseket is kaptunk, ami összhangban van az elméleti modell által várt összefüggésekkel. Logikus, hogy minél nagyobb belső motiváltság jellemzi a tanulókat annál kevésbé igaz rájuk a motiválatlanság. Az önjutalmazó motiváció azonban nem csak a motiválatlansággal, hanem a külső ösztönzőkkel is negatív kapcsolatban áll. Azaz, az erős belső elköteleződésű diákokat a külső szabályozók már inkább hátráltatják.

Számos tanulmány kimutatta, hogy az iskolai évek előrehaladtával a tanulók iskolai tanuláshoz kapcsolódó intrinzik motivációja csökken (lásd például Józsa et al., 2020 áttekintését). Ezzel szemben eredményeink szerint magasabb intrinzik motivációval jellemezhetőek azok a tanulók, akik hosszabb ideje tanulnak hangszeren játszani. Az eredmény összhangban van Hallam és munkatársai (2020) kutatásának következtetéseivel. A hangszertanulással töltött idő alapján az alapfokú és középfokú művészeti képzésben részt vevő diákok esetén két motivációs típus, az introjekció és az azonosulás is szignifikánsan magasabb a középfokú tanulmányokat folytatóknál, mint az alapfokúak esetében. Úgy tűnik tehát, hogy a tanulással töltött idő előrehaladtával ezek a motívumok erősödnek. Ennek egyik lehetséges magyarázata lehet az is, hogy azok a tanulók, akik elvesztették az intrinzik motivációjukat, korábban már abbahagyták a hangszertanulást. Így a kevésbé motivált tanulók az alapfokú hangszeroktatásban még jelen vannak, a középfokúban azonban 
már nincsenek. Azok, akik magasabb évfolyamon is tanulnak hangszeren játszani továbbra is erős, erősödő intrinzik motivációval jellemezhetők. Ezzel szemben a szülők részéről jövő extrinzik motiváció magasabb életkorban kisebb mértékű. Ez alapján úgy tűnik, hogy a hangszertanulásban magasabb életkorban az intrinzik motiváció válik meghatározóbbá a külső ösztönzőkkel szemben.

Az öndeterminációs elmélet szerint, ha saját magunk döntünk valami mellett, és magáért a cselekvésért kezdünk el egy tevékenységet, akkor az nagyobb mértékben válik az énünk részévé. A döntés lehetőségének, az autonómia érzésének a biztosítása jelentős mértékben erősítheti a tanuló motiváltságát. Eredményeink szerint azok a tanulók, akik maguk is beleszólhattak a hangszertanulásukba, maguk választhatták a hangszert, jellemzően motiváltabbak. A fiúk és a lányok között nincs szignifikáns különbség az egyes motívumokban.

A diákok hangszereit csoportokba rendeztük, hogy lássuk, van-e eltérés az egyes hangszertípusokat tanuló diákok motiváltságában. Az azonosulás esetén szignifikáns különbség van a vonós és a pengetős hangszeren tanulók között, valamint a vonós és a billentyűs hangszeren játszók között. Leginkább a vonós hangszeren játszó diákokra jellemző a zenetanulással való azonosulás mint tanulási motívum.

A hangszertanulás iránt motiválatlan diákok az iskolai tantárgyakat (énekzene, irodalom, történelem, idegen nyelv) sem kedvelik. Ellenben a hangszertanulás iránti belső elköteleződés, intrinzik motiváció nem jár együtt az iskolában tanult többi tantárgy kedvelésével.

Kutatásunkban a hangszeres zenét tanuló diákok adtak önjellemzést a saját motivációjukról. A következő vizsgálatokba célszerű a szülők és a pedagógusok bevonása is. Fontos információval szolgálhat a motivációról a diákok, a pedagógusok és a szülők megítélésének az összevetése. A pedagógusok bevonásakor érdemes lehet vizsgálni a tanári visszajelzést, a tanítási módszereket, a tanulói autonómia támogatását. A szülők esetében ugyancsak célszerü vizsgálni a zenetanulás támogatását összevetve azt a tanuló hangszertanulási motivációjával. A későbbiekben a hangszertanulással kapcsolatban a tanulók céljait, az énképet, a tanulási módszereket, a gyakorlásra fordított időt, a barátok és a kortársak hatását is figyelembe kell venni. A motiválatlanság okainak feltárása hozzájárulhat olyan módszerek és eszközök létrehozásához, fejlesztéséhez, amelyek csökkenthetik a lemorzsolódást a hangszeres tanulmányok során.

\section{Köszönetnyilvánítás}

A tanulmány elkészítését a Magyar Tudományos Akadémia Közoktatásfejlesztési Kutatási Programja támogatta. A kutatás az MTA-MATE Kora Gyermekkor Kutatócsoport keretében valósult meg. 


\section{Irodalom}

2011. évi CXC. törvény a nemzeti köznevelésről. https://net.jogtar.hu/ getpdf?docid $=$ a1100190.tv\&targetdate $=\&$ printTitle $=2011 .+\%$ C3\%A9vi + CXC. $+\mathrm{t}$ \%C3\%B6rv\%C3\%A9ny

Anguiano, K. R. (2006). Motivational predictors of continuing motivation and achievement for early adolescent instrumental music students. PhD dissertation. University of Iowa.

Appelgren, A., Osika, W., Theorell, T., Madison, G. \& Bojner Horwitz, E. (2019). Tuning in on motivation: Differences between non-musicians, amateurs, and professional musicians. Psychology of Music, 030573561986143. https://doi. org/10.1177/0305735619861435

Bayley, J. G. (2004). The procedure by which teachers prepare students to choose a musical instrument. Update: Applications of Research in Music Education, 22(2), 23-34. https://doi.org/10.1177/87551233040220020104

Bernabé-Valero, G., Blasco-Magraner, J. S. \& Moret-Tatay, C. (2019). Testing motivational theories in music education: The role of effort and gratitude. Frontiers in Behavioral Neuroscience, 13(172),1-9. https://doi. org/10.3389/fnbeh.2019.00172

Cantero, I. M. \& Jauset-Berrocal, J. A. (2017). Why do they choose their instruments? British Journal of Music Education, 34(2), 203-215. https://doi. org/10.1017/S0265051716000280

Comeau, G., Huta, V., Lu, Y. \& Swirp, M. (2019). The Motivation for Learning Music (MLM) questionnaire: Assessing children's and adolescents' autonomous motivation for learning a musical instrument. Motivation and Emotion, 43(5), 705-718. https://doi.org/10.1007/s11031-019-09769-7

Creech, A. (2001). Play for me: An exploration into motivations, issues and outcomes related to parental involvement in their children's violin study. PhD dissertation, University of Sheffield, Department of Music.

Creech, A. \& Hallam, S. (2010). Music education in the 21st century in the United Kingdom: Achievements, analysis and aspirations. Institute of Education.

Degner, S., Lehmann, A. C. \& Gruber, H. (2003). Expert learning in the domain of jazz guitar music. In R. Kopiez, A. C. Lehmann, I. Wolther, \& C. Wolf (Eds.), Proceedings of the 5 th Triennial ESCOM Conference (pp. 384-388). University of Music and Drama.

Dohány, G. (2009). Zenei élmény az énekórán? Iskolakultúra Online, 3(1), 70-79.

Evans, P. (2015). Self-determination theory: An approach to motivation in music education. Musicae Scientiae, 19(1), 65-83.

Evans, P., McPherson, G. E. \& Davidson, J. W. (2013). The role of psychological needs in ceasing music and music learning activities. Psychology of Music, 41, 600-619. 
Felelős Szülők Iskolája (n.d.). https://felelosszulokiskolaja.hu/felelos-szulo/ hangszertanulas-motivacio?fbclid=IwAR35Li7Sk2qw5gchnMeDPW2YR0nJZxltcBihoNbbUfNP58v6ovEZa1nRiw

Földi, F. \& Józsa, K. (megj. alatt). A Hangszertanulási motiváció kérdőív magyar adaptációja.

Freer, E. \& Evans, P. (2019). Choosing to study music in high school: Teacher support, psychological needs satisfaction, and elective music intentions. Psychology of Music, 47(6), 781-799. https://doi.org/10.1177/0305735619864634

Grolnick, W. S., Levitt, M. R., Caruso, A. J. \& Lerner, R. E. (2021). Effectiveness of a Brief Preventive Parenting Intervention Based in Self-Determination Theory. Journal of Child and Family Studies, 30(4), 905-920. https://doi. org/10.1007/s10826-021-01908-4

Hallam, S. (2002). Musical motivation: Towards a model synthesising the research. Music Education Research, 4(2), 225-244. https://doi. org/10.1080/1461380022000011939

Hallam, S (2004). Sex differences in the factors which predict musical attainment in school aged students. Bulletin of the Council for Research in Music Education, 161-162, 107-117.

Hallam, S. (2013). What predicts level of expertise attained, quality of performance, and future musical aspirations in young instrumental players? Psychology of Music, 41(3), 265-289. https://doi.org/10.1177/0305735611425902

Hallam, S., Creech, A., Papageorgi, I., Gomes, T., Rinta, T., Varvarigou, M. \& Lanipekun, J. (2016). Changes in motivation as expertise develops: Relationships with musical aspirations. Musicae Scientiae, 20(4), 528-550. https://doi. org/10.1177/1029864916634420

Hallam, S., Creech, A., Varvarigou, M. \& Papageorgi, I. (2020). Are there differences in practice depending on the instrument played? Psychology of Music, 48(6), 745-765. https://doi.org/10.1177/0305735618816370

Hallam, S., Varvarigou, M., Creech, A., Papageorgi, I., Gomes, T., Lanipekun, J. \& Rinta, T. (2017). Are there gender differences in instrumental music practice? Psychology of Music, 45(1), 116-130. https://doi.org/10.1177/0305735616650994

Hallam, S., Rogers, L. \& Creech, A. (2008). Gender differences in musical instrument choice. International Journal of Music Education, 26(1), 7-19. https://doi. org/10.1177/0255761407085646

Hargreaves, D. J. \& Marshall, N. A. (2003). Developing identities in music education. Music Education Research, 5(3), 263-273.

Héjja, B. (2016). Az alapfokú és középfokú zeneoktatás helyzete Magyarországon. Parlando, 2, 1-30.

Héjja, E. B. (2018). A zeneművészeti szakgimnazista tanulók iskolaválasztási motivációi. Iskolakultúra, 28(1-2), 104-117. 
Ho, W. C. (2011). Parental support and student learning of musical instruments in Hong Kong. Visions of Research in Music Education, 19(5), 1-53. https://doi. org/10.1080/1461380032000126355

Jakobicz, D., Wamzer, G. \& Józsa, K. (2018). Motiválás az ének-zene órákon. Gyermeknevelés Tudományos Folyóirat, 6(2), 18-31. https://doi. org/10.31074/gyn201821831

Janurik, M. (2007). Áramlatélmény az iskolai ének-zene órákon. Magyar Pedagógia, 107(4), 295-320.

Janurik, M. (2008). A zenei képességek szerepe az olvasás elsajátításában. Magyar Pedagógia, 108(4), 289-317

Janurik, M. \& Józsa, K. (2018). Az iskolai zenetanulás iránti motivációt alakító néhány tényező. Gyermeknevelés Tudományos Folyóirat, 6(2), 5-17. https://doi. org/10.31074/gyn20182517

Janurik, M., Szabó, N. \& Józsa, K. (2020). A zenei énkép jellemzői és összefüggése a zenei képességekkel hetedik osztályosok körében. Magyar Pedagógia, 120(2), 171-200.

Józsa, K., Kis, N. \& Barrett, K. C. (2019). Mastery motivation, parenting, and school achievement among Hungarian adolescents. European Journal of Psychology of Education, 34, 317-339. https://doi.org/10.1007/s10212-018-0395-8

Józsa, K., Barrett, K. C., Amukune, S., Calchei, M., Gharib, M., Iqbal Hashmi, S., Podráczky, J., Nyitrai, Á. \& Wang, J. (2020). Implications of the DMQ for Education and Human Development: Culture, Age and School Performance. In G. A. Morgan, H.-F. Liao, \& K. Józsa (Eds.), Assessing Mastery Motivation in Children Using the Dimensions of Mastery Questionnaire (DMQ) (pp. 133-158). Szent István Egyetem.

Józsa, K. \& Fazekasné Fenyvesi, M. (2007). Tanulásban akadályozott gyermekek tanulási motivációja. Iskolakultúra Online, 1(1), 76-92.

Kiyoshi, A. \& Csíkszentmihályi, M. (1998). The quality of experience of Asian American adolescents in activities related to future goals. Journal of Youth and Adolescence, 27(2), 141-163. https://doi.org/10.1023/A:1021659612041

Kő, N., Pajor, G. \& Szabó, M. (2017). Motiváció. In N. Kollár, K. \& Szabó, É. (Eds), Pedagógusok pszichológiai kézikönyve I. (pp. 303-347). Osiris Kiadó.

Längler, M., Nivala, M. \& Gruber, H. (2018). Peers, parents and teachers: A case study on how popular music guitarists perceive support for expertise development from "persons in the shadows". Musicae Scientiae, 22(2), 224-243. https://doi. org/10.1177/1029864916684376

MacIntyre, P. D., Schnare, B. \& Ross, J. (2018). Self-determination theory and motivation for music. Psychology of Music, 46(5), 699-715. https://doi. org $/ 10.1177 / 0305735617721637$

Macmillan, J. (2004). Learning the piano: A study of attitudes to parental involvement. British Journal of Music Education, 21(3). 295-311. https://doi. org/10.1017/S0265051704005807 
McPherson, G. E. (2000). Commitment and practice: Key ingredients for achievement during the early stages of learning a musical instrument. Bulletin of the Council for Research in Music Education, 147, 122-127.

McPherson, G. E. \& McCormick, J. (2006). Self efficacy and music performance. Psychology of Music, 34(3), 322-336. https://doi.org/10.1177/0305735606064841

McPherson, G. E. \& Zimmerman, B. J. (2002). Self-regulation of musical learning: A social cognitive perspective. In R. Colwell \& C. Richardson (Eds.), The new handbook of research of music teaching and learning (pp.130-175). Oxford University Press.

McPherson, G. E. (2009). The role of parents in children's musical development. Psychology of Music, 37(1), 91-110. https://doi.org/10.1177/0305735607086049

McPherson, G. E., Davidson, J. W. \& Evans, P. (2016). Playing an instrument. In McPherson, G. (Ed.), The child as musician: A handbook of musical development (pp. 401-421). Oxford University Press. https://doi.org/10.1093/acprof:o so/9780198530329.001.0001

McPherson, G. E. \& O’Neill, S. A. (2010). Students' motivation to study music as compared to other school subjects: A comparison of eight countries. Research Studies in Music Education, 32(2), 101-137. https://doi. org/10.1177/1321103X10384202

Mitchell, S. \& DellaMattera, J. (2010). Teacher support and student's self-efficacy beliefs. Journal of Contemporary Issues in Education, 5(2), 24-35. https://doi. org/10.20355/C5X30Q

Oliveira, A., Ribeiro, F. S., Ribeiro, L. M., McPherson, G. \& Oliveira-Silva, P. (2021). Disentangling motivation within instrumental music learning: a systematic review. Music Education Research, 23(1), 105-122. https://doi.org/10.1080/146 13808.2020.1866517

Pintér, T. K. \& Csíkos, Cs. (2020). Tanulók, szülők és tanárok perspektívái az iskolai zenei nevelés céljáról és feladatáról. Iskolakultúra, 30(7), 3-25. https://doi. org/10.14232/ISKKULT.2020.7.3

Renwick, J. M. \& McPherson, G. E. (2009). Multiple motives: Profiles of young Australians' reasons for musical engagement. In Williamon, A., Pretty, S. \& Buck, R. (Eds.), Proceedings of the International Symposium on Performance Science (pp. 469-474). Association Européenne des Conservatoires, Académies de Musique et Musikhochschulen (AEC).

Renwick, J., \& Reeve, J. (2012). Supporting motivation in music education. In G. E. McPherson \& G. F. Welch (Eds.), The Oxford handbook of music education, volume 1 (pp. 143-162). Oxford University Press.

Ryan, R. M. \& Deci, E. L. (2009). Promoting self-determined school engagement: Motivation, learning, and well-being. In K. R. Wentzel \& A. Wigfeld (Eds.), Handbook on motivation at school (pp. 171-196). Routledge. 
Ryan, R. M. \& Deci, E. L. (2017). Self-Determination Theory: An Introduction and Overview. Chapter 1. In Ryan, R. M., \& Deci, E. L. (Eds.), Self-Determination Theory Basic Psychological Needs in Motivation, Development, and Wellness (pp. 3-25). Guilford Press.

Sichivitsa, V. O. (2007). The influences of parents, teachers, peers and other factors on students' motivation in music. Research Studies in Music Education, 29(1), 55-68. https://doi.org/10.1177/1321103X07087568

Sloboda, J. (2001). Emotion, functionality and the everyday experience of music: Where does music education fit? Music Education Research, 3(2), 243-253. https://doi.org/10.1080/14613800120089287

Szabó, N. (2018a). Zenesziget. Játékosítás (gamifikáció) digitális eszközökkel az ének-zene oktatásban. Gyermeknevelés Tudományos Folyóirat, 6(2), 97-107. https://doi.org/10.31074/gyn2018297107

Szabó, N. (2018b). A cél szentesítiaz (IKT-)eszközt a zeneoktatásban? Gyermeknevelés Tudományos Folyóirat, 6(2), 132-138. https://doi.org/10.31074/gyn20182132138

Szabó, N. (2021). Zenei fejlesztés első osztályosok körében digitális eszközök használatával. PhD-értekezés. Szegedi Tudományegyetem, Neveléstudományi Doktori Iskola.

Szende, O. (2000). A hangszertanulási szándék vizsgálata. Előkísérlet ismertetése. Parlando: Zenepedagógiai Folyóirat, 42(3-4), 36-40.

Szivárványzene (2013). A hangszerválasztásról https://szivarvanyzene.wordpress. com/2013/05/30/a-hangszervalasztasrol/ 


\section{Földi, F. \& Józsa, K.}

\section{Motivational factors involved in learning instrumental music}

In this study, we analyze the motivation of students learning musical instrument. Hungarian motivational research has so far barely examined the motivational background of instrumental music learning, so we focus on this area. Our research used the Motivation for Learning Music (MLM) questionnaire, which we adapted to Hungarian. The test tool was developed based on self-determination theory. It contains a total of 25 Likert-type statements, which are organized into the following factors: amotivation, external regulation, introjection, identification, and intrinsic motivation. 151 students took part in the study between the age of 10-18. The factorial validity of the measuring instrument and the reliability of the five scales are adequate. Our results show that the motivation of secondary school students is stronger than that of primary school students. There is a difference in the commitment of students to different instruments. However, there is no difference in motivation between boys and girls. Supporting the child's independence and autonomy plays a role in the motivation to learn the instrument. Our results may contribute to a deeper understanding of the motivation of students learning music.

Keywords: motivation, learning musical instrument, self-determination theory

Földi Fanni: https://orcid.org/0000-0002-3736-7178

Józsa Krisztián: https://orcid.org/0000-0001-7174-5067 